\title{
TRIDIONE COMPARED WITH MALIDONE IN THE TREATMENT OF PETIT MAL*
}

\author{
BY
}

\author{
A. J. M. BUTTER
}

From St. David's Hospital, London, N.18

Tridione $(3,5,5,-$ trimethyloxazolidine $-2: 4$ dione) has been extensively used in the treatment of petit mal for five years, and its success in more than $60 \%$ of cases has been well established. Its dangers and limitations are also well recognized (Richards and Everett, 1944 ; Lennox, 1947).

During the past two years 25 men between the ages of 17 and 52 who suffered from frequent petit mal, and 15 of whom had previously been treated with tridione, were given a similar substance, namely " malidone" (3-allyl-5-methyloxazolidine$2: 4$-dione), in an attempt to compare the relative merits of the two drugs.

The average dosage was one capsule $(0 \cdot 3 \mathrm{~g}$.) thrice daily. The results are compared with those obtained in a previous series of 35 cases treated with tridione (Table I).

\section{TABLE I}

COMPARISON OF RESULTS OF TREATMENT OF PETIT MAL BY TRIDIONE AND MALIDONE

\begin{tabular}{l|c|c}
\hline & $\begin{array}{c}\text { Iridione } \\
\text { (35 cases) }\end{array}$ & $\begin{array}{c}\text { Malidone } \\
\text { (25 cases) }\end{array}$ \\
\hline $\begin{array}{l}\text { Petit mal completely or almost } \\
\text { completely controlled }\end{array}$ & $25 \%$ & $20 \%$ \\
\hline $\begin{array}{l}\text { Petit mal attacks reduced by } \\
\text { half or more than half }\end{array}$ & $37 \%$ & $44 \%$ \\
\hline $\begin{array}{l}\text { Slightly benefited } \\
\text { No change }\end{array}$ & $12 \%$ & $16 \%$ \\
\hline Worse & $20 \%$ & $16 \%$ \\
\hline
\end{tabular}

As will be seen from this table, the results are closely comparable as far as the control of petit mal is concerned.

Previous experience in the tridione series in this hospital had shown that toxic reactions are less

* Communication to the International League against Epilepsy in January, 195:. likely to be produced if the drug is introduced gradually, and for this reason I have advised an initial dose of one capsule daily for several days, this being increased to the optimum number of capsules which without toxic reactions will effect the greatest reduction in the number of attacks. Similar caution in using malidone would appear to be advisable.

Table Il compares the incidence of toxic reactions produced by the two drugs.

TABLE II INCIDENCE OF TOXIC SYMPTOMS AND SIGNS

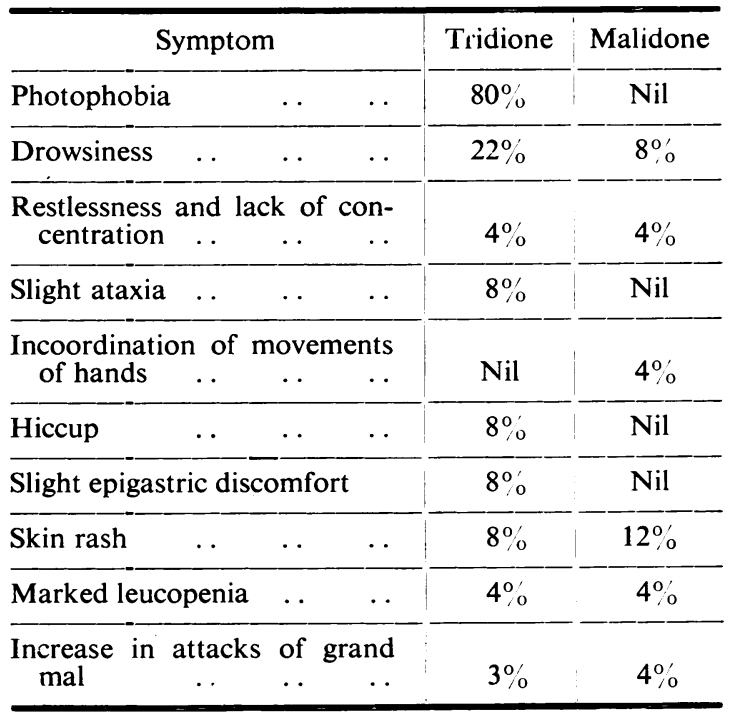

The most striking differences are the absence of photophobia and the relative infrequency of drowsiness in the malidone series. Photophobia, or " the glare phenomenon", in patients taking tridione, may be sufficiently severe to necessitate the wearing of dark glasses. Although tolerance has been found to be acquired in the majority of cases after a 
few weeks, it is obviously an advantage to have a drug which does not produce a symptom sufficiently trying to deter some patients from persevering with the treatment. Malidone also appears in this series to have the advantage over tridione in not producing ataxia or gastric irritation.

\section{Summary}

Twenty-five patients with petit mal, 15 of whom had previously becn taking tridione, were treated during the past two years with "malidone".

The therapeutic results with malidone were broadly similar to those obtained with tridione, $80 \%$ of the patients deriving benefit.
Photophobia is common in patients taking tridione $(80 \%)$ but malidone did not produce photophobia in any case in this series. Other toxic symptoms or signs were usually less severe and more transitory than those experienced in the series treated with tridione.

I wish to thank Messrs. British Schering, Limited, for generous supplies of " malidone", and the British Schering Research Institute for their biological report on various derivatives of oxazolidine-2:4-dione.

\section{REFERENCES}

Richards, R. K., and Everett, G. M. (1944). Fed. Proc., 3, 39.

Lennox, W. G. (1947). J. Amer. med. Assoc., 134, 138.

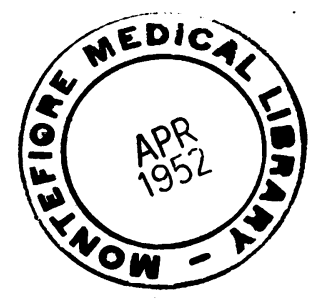

